\title{
HUBUNGAN LOGAM BERAT TIMBAL (Pb) DAN KADMIUM (Cd) TERLARUT DENGAN KELIMPAHAN FITOPLANKTON DI SUNGAI SILANDAK SEMARANG
}

\author{
The Heavy Metal Correlation of Dissolved Lead $(\mathrm{Pb})$ and Cadmium $(\mathrm{Cd})$ with The Abundance \\ of Phytoplankton in Silandak River Semarang
}

\section{Helmi Ardi, Siti Rudiyanti *), Bambang Sulardiono}

Program Studi Manajemen Sumberdaya Perairan, Departemen Sumberdaya Akuatik

Fakultas Perikanan dan Ilmu Kelautan, Universitas Diponegoro

Jl. Prof. Soedarto, SH, Tembalang, Semarang, Jawa Tengah - 50275, Telp/Fax. +6224 7474698

Email : helmiardi27@yahoo.com

\begin{abstract}
ABSTRAK
Sungai Silandak terletak di Kota Semarang, Jawa Tengah. Sungai ini menerima limbah yang berasal dari kegiatan industri plastik yang dialirkan ke perairan, dan juga menerima aliran limbah rumah tangga serta terdapat banyak sarana transportasi air di bagian muara sungai.Limbah yang berasal dari industri tersebut mengandung logam berat timbal dan kadmium.Penelitian dilakukan pada bulan April 2016 - Mei 2016 di Sungai Silandak yang bertujuan untuk mengetahui konsentrasi kadmium dan timbal, mengetahui kelimpahan danstruktur komunitas fitoplankton, dan mengetahui hubungan kadmium dan timbal dengan kelimpahan fitoplankton. Metode penelitian yang digunakan adalah metode survei dengan teknik samplingpurposive sampling. Hasil penelitian menunjukkan konsentrasi kadmium di lokasi penelitian berkisar antara 0,0007 - 0,001 $\mathrm{mg} / \mathrm{l}$, sedangkan konsentrasi timbalberkisar antara 0,002 - 0,007 mg/l. Kelimpahan fitoplankton berkisar antara 1826 - 6730 ind/l, indeks keanekaragaman (H') dengan angka 1.747 - 2.828, Indeks dominasi (d) diperoleh hasil dengan angka $0.077-0.284$, dan indeks keseragaman (e) dengan angka $0.645-0.890$. Tidak ada hubungan yang signifikan antara kadmium dengan kelimpahan fitoplankton dengan angka koefisien korelasi (r) sebesar 0.179 menunjukkan korelasi lemah.Tidak ada hubungan yang signifikan antara logam berat timbal dengan kelimpahan fitoplankton, diperoleh angka koefisien korelasi (r) sebesar 0.261 menunjukkan korelasi lemah.PCA (Principle Component Analysis) digunakan untuk mengetahui hubungan kadmium dan timbal dengan kelimpahan genera fitoplankton. Terdapat hubungan signifikan logam berat timbal dengan kelimpahan genus Dyctyocha sp dan Bacteriastrum sp di level 0.05 dari rentang kepercayaan $95 \%$, korelasi kuat negatif dengan koefisien korelasi 0.68 .
\end{abstract}

Kata Kunci :Kadmium; Cd; Timbal; Pb; Kelimpahan Fitoplankton;Logam Berat; SungaiSilandak.

\begin{abstract}
Silandak river is located in Semarang, Central Java. This river is suspect to receiving waste came from plastic industry activity which is streamed to the water, and also receiving household waste stream and there are plenty of water transportation in the section of the estuary. Waste from the industry is suspected contain heavy metals cadmium and lead.The study was conducted in April 2016 - May 2016 in the River of Silandak which aimed to determine the concentration of cadmium and lead, to determine the abundance and the phytoplankton community structure, and to determine the correlation of cadmium and lead with the abundance of phytoplankton. The study used survey method with purposive sampling technique. The results showed the concentration of cadmium in the study locations was within the range of 0.0007 to $0.001 \mathrm{mg} / \mathrm{l}$, while the concentration of lead was within the range of 0.002 to $0.007 \mathrm{mg} / \mathrm{l}$. The abundance of phytoplankton ranged between 1826 - 6730 indll, the rate of diversity index $\left(H^{\prime}\right)$ was within the range of $1.747-2.828$, the dominance index $(d)$ obtained results within the rate of 0.077 - 0.284 , and evenness index (e) within the rate of 0.645 0.890. There was no significant correlation between cadmium with the abundance of phytoplankton with a correlation coefficient ( $r$ ) of 0.179 which means weak correlations. There was no significant correlation between the heavy metals lead with the abundance of phytoplankton, the rate of the correlation coefficient $(r)$ of 0.261 which means weak correlations. PCA (Principle Component Analysis) is used to determine the correlation cadmium and lead with the abundance of phytoplankton genus. There was a significant correlations of heavy metals lead with the abundance Dyctyocha sp and Bacteriastrum sp genus at 0.05 levels the range of 95\%, a strong negative correlation with a correlation coefficient of - 0.68 .
\end{abstract}

Keywords: Cadmium; Cd; Lead; Pb;Phytoplankton Abundance; Heavy Metal;Silandak River.

*) Penulis penanggungjawab

() Copyright by Management of Aquatic Resources (MAQUARES) 


\section{PENDAHULUAN}

Kemajuan pesat dari teknologi dan industri yang diciptakan oleh manusia telah memberikan banyak dampak bagi manusia.Dampak positif sangat diharapkan oleh manusia dalam rangka meningkatkan kualitas dan kenyamanan hidup.Namun, dampak yang bersifat negatif tidak diharapkan terutama pencemaran perairan karena limbah dari aktivitas industri lebih banyak dialirkan ke perairan yang dapat menurunkan kualitas lingkungan.

Sungai Silandak terletak di Jalan Siliwangi, Kelurahan Tambak Harjo, Kecamatan Semarang Barat, Kota Semarang, Jawa Tengah.Sungai ini menerima limbah yang berasal dari kegiatan industri plastik yang dialirkan ke perairan, dan juga menerima aliran limbah rumah tangga yang berasal dari pemukiman rumah penduduk.Selain itu, Sungai Silandak merupakan sungai yang merupakan sungai penampungan terakhir dari sistem drainase perkotaan Kota Semarang, dan terdapat sarana transportasi air di bagian muara sungai.

Limbah industri plastik dan sumber lain tersebut mengandung unsur dan senyawa logam berat yang mempunyai daya racun. Logam berat yang dialirkan dari proses produksi industri limbah plastik dan sumber lainnya mengandung unsur $\mathrm{Cd}$ dan $\mathrm{Pb}$. Kamdium $(\mathrm{Cd})$ dan timbal $(\mathrm{Pb})$ merupakan logam non esensial bersifat toksik dan tidak dapat dimanfaatkan oleh tubuh. Limbah industri yang mengandung senyawa logam berat non esensial bukan hanya bersifat toksik terhadap organisme air, tetapi juga terhadap hewan dan manusia. Menurut Palar (2008) daya racun yang dimiliki oleh bahan buangan industri memang tidak sama. Semua itu tergantung pada jenis hasil buangan dan jenis organisme yang terkena. Jenis buangan yang mempunyai toksisitas tinggi tentu akan menyerang semua jenis organisme. Tetapi untuk bahan buangan yang toksisitasnya sedang dan rendah, maka tingkat toleransi dan penetralisasi menjadi hal penentu.

Toksisitas tersebut akan berdampak terhadap kelimpahan dan keanekaragaman fitoplankton sebagai Primary Producen, daya toleransi dan penetralisir racun setiap biota memiliki perbedaan. Biota yang mempunyai rentang toleransi yang lemah akan mati danmempengaruhi distribusi kelimpahan dan keanekaragaman fitoplankton. Fitoplankton merupakan indikator kesuburan suatu perairan.

Tujuan utama dari penelitian yang dilakukan pada bulan April - Mei 2016 ini adalah mengetahui konsentrasi logam berat kadmium $(\mathrm{Cd})$ dan timbal $(\mathrm{Pb})$, kelimpahan dan struktur komunitas fitoplankton dan hubungan konsentrasi kadmium $(\mathrm{Cd})$ dan timbal $(\mathrm{Pb})$ dengan kelimpahan fitoplankton di Sungai Silandak, Semarang.

\section{MATERI DAN METODE}

Materi yang digunakan didalam pengukuran konsentrasi logam berat kadmium $(\mathrm{Cd})$ dan timbal $(\mathrm{Pb}) \mathrm{di}$ Sungai Silandak adalah air sungai.Metode yang digunakan dalam penelitian ini menggunakan metode survei.Teknik metode survei dengan pengambilan sampel air secaraComposite Area Integrated, dan plankton secara pasif dengan metode penyaringan (filtration method) di tengah sungai, peralihan sungai dan muara sungai selanjutnya analisa di laboratorium. Metode sampling dilakukan secara Purposive Sampling. Titik sampling dalam penelitian ini dapat dilihat dalam peta penelitian sebagai berikut :

\section{Lokasi Sampling}

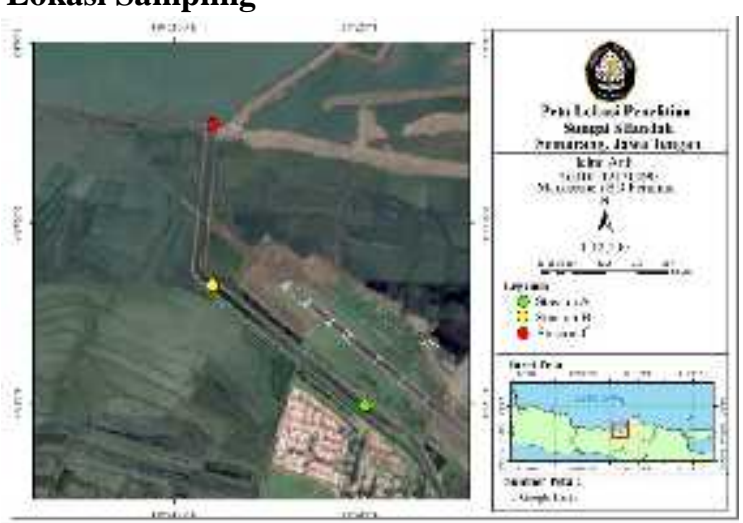

Stasiun A merupakan lokasi tengah sungai dekat dengan industri plastik $\mathrm{S}=06^{0} 58^{\prime} 5,09^{\prime \prime}$ dan $\mathrm{E}=110^{\circ} 21^{\prime} 1,12^{\prime \prime}$. Stasiun B merupakan lokasi peralihan sungai dekat dengan limbah domestik $S=06^{\circ} 57^{\prime} 44,64^{\prime \prime}$ dan $E=110^{\circ}$ 21 ' 35,56 '.

Stasiun $\mathrm{C}$ merupakan lokasi muara sungai terdapat sarana transportasi air $\mathrm{S}=06^{\circ} 57^{\prime} 16,26^{\prime \prime}$ dan $\mathrm{E}=110^{\circ} 21^{\prime} 34,79^{\prime \prime}$.

Gambar 1. Peta Lokasi Penelitian

\section{Uji Konsentrasi Logam Berat Timbal (Pb) dan Kadmium (Cd)}

Sampel air dengan wadah botol polyethylene dari setiap stasiun diawetkan dengan cara ditambahkan $\mathrm{HNO}^{3}$ hingga pH mencapai 2 untuk kemudian dianalisis konsentrasi logam timbal dan kadmium di laboratorium Balai Besar Teknologi Pencegahan Pencemaran Industri (BBTPPI), Semarang. Prosedur pengukuran konsentrasi timbal dan kadmiumpada sampel air mengacu Standard Method American Public Health Association APHA, AWWA, WPCF (2012), 3030. B. 3111. C dan 3030. B. 3111. B tentang perlakuan contoh air untuk analisis logam (pengukuran konsentrasi logam terlarut) dengan AAS (Atomic Absorption Spectophotometer) dengan merk Agilent Technologies 200 Series AA Ultra UV. Batas limit deteksi untuk kadmium dengan nilai $(<0.001)$ dan timbal $(<0.003)$. 


\section{Metode Pengamatan Fitoplankton}

Sampel yang telah diawetkan dikocok terlebih dahulu dengan cara botol sampel dikocok perlahan-lahan beberapa kali sampai teraduk dan tercampur. Setelah itu, diambil sebanyak $1 \mathrm{ml}$ dan diletakkan di SedgwickRafter yang telah diletakkan object glass sebagai penutup.Kemudian diamati di bawah mikroskop binoculer.

1) Identifikasi dan Perhitungan

Identifikasi dan perhitungan dilakukan dengan bantuan mikroskop binoculer perbesaran 100x (ketebalan gelas penutup yang terbuat dari object glass mempersulit pengamatan pada perbesaran yang lebih tinggi),dengan dilakukan pengulangan 3 kali pada 10 lapang pandang yang berbeda.

a). Identifikasi

Sampel plankton diamati dengan mikroskop dan diidentifikasi dengan menggunakan bantuan buku - buku kunci identifikasi karangan Yamaji (1996) dan Belinger (2010).

b). Perhitungan

Plankton dihitung dengan alat pencacah Sedgwick-Rafter berukuran panjang dan lebar petak $50 \mathrm{~mm}$ x $20 \mathrm{~mm}$ dengan tebal $1 \mathrm{~mm}$, dengan demikian luasnya $1000 \mathrm{~mm}^{2}$, volumenya $1000 \mathrm{~mm}^{3}$ dan luas lapang pandang $\mathrm{L}=$ $0.25 \mathrm{~mm}^{2}$. Perhitungan dilakukan dengan mengikuti gambar petak Sedgwick-Rafter, yaitu dimulai dari petak ke 5-15-25-35-45 kemudian turun ke bawah dengan jarak 10 petak dan digeser ke kiri dengan jarak masing-masing 10 petak.

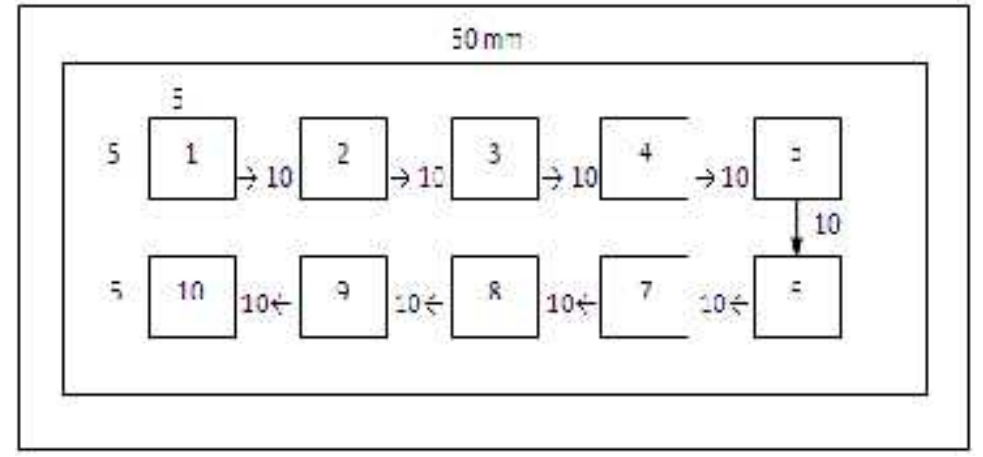

Gambar 2. Sistematika pengamatan fitoplankton diSedgwick-Rafter

\section{Analisis Data Fitoplankton}

Analisis data dengan menggunakan perhitungan kelimpahan fitoplankton, indeks keanekaragaman, indeks keseragaman, dan indeks dominansi

a. Kelimpahan Fitoplankton

Perhitungan kelimpahan fitoplankton digunakan rumus dari American Public Health Association (APHA, 1976) yaitu:

$$
\mathrm{N}=\frac{\mathrm{I}}{\mathrm{L}} \times \frac{\mathrm{F}}{\mathrm{\mu}} \times \frac{\mathrm{V}}{\mathrm{v}} \times \frac{1}{\mathrm{w}}
$$

Dimana:

$$
\begin{array}{ll}
\mathrm{N} & =\text { Jumlah fitoplankton per liter } \\
\mathrm{T} & \text { = Luas total petak Sedgwick-Rafter }\left(1000 \mathrm{~mm}^{2}\right) \\
\mathrm{L} & \text { = Luas lapang pandang mikroskop }\left(3,14 \times 0.25 \mathrm{~mm}^{2}=0.785 \mathrm{~mm}^{2}\right) \\
\mathrm{P} & \text { = Jumlah fitoplankton yang tercacah } \\
\mathrm{p} & \text { = Jumlah lapang pandang yang diamati }(10 \text { petak }) \\
\mathrm{V} & =\text { Volume sampel fitoplankton yang tersaring }(50 \mathrm{ml}) \\
\mathrm{V} & \text { = Volume sampel fitoplankton dalam Sedgwick Rafter }(1 \mathrm{ml}) \\
\mathrm{W} & \text { = Volume sampel fitoplankton yang tersaring }(100 \text { liter })
\end{array}
$$

b. Indeks keanekaragaman

Perhitungan Indeks Keanekaragaman $(\mathrm{H})$ dilakukan dengan menggunakan formulasi Shannon-Wiener (Odum, 1993), yaitu:

$$
H=-\sum_{i=1}^{s} P i \ln H i
$$


Dimana:

$\mathrm{H}$ = Indeks keanekaragaman Shannon-Wiener

$\mathrm{Pi}=$ Peluang spesies atau genera $\mathrm{i}$ dari total individu $(\mathrm{ni} / \mathrm{N})$

$\mathrm{S}=$ Jumlah spesies atau genera

$\mathrm{Ni}=$ Jumlah individu spesies atau genera ke-i

$\mathrm{N}=$ Jumlah total individu

Dengan kriteria $\mathrm{H}$ yaitu:

$\mathrm{H}<1=$ Komunitas biota tidak stabil atau kualitas air tercemar berat

$1 \leq \mathrm{H}^{\prime} \leq 3 \quad=$ Stabilitas komunitas biota sedang atau tercemar sedang

$\mathrm{H}^{\prime}>3=$ Stabilitas komunitas biota stabil atau kualitas air bersih

c. Indeks keseragaman

Untuk mengetahui berapa besar kesamaan penyebaran jumlah individu setiap spesies pada tingkatan komunitas, digunakan indeks keseragaman (Odum, 1971):

$=\frac{H^{r}}{H \max }$

Dimana:

$\mathrm{e} \quad=$ Indeks keseragaman

$\mathrm{H}^{\prime} \quad$ = Indeks keanekaragaman

$\mathrm{H} \max \quad=\ln \mathrm{s}$ dimana s adalah jumlah spesies atau genera

e. Indeks dominansi

Indeks dominansi dihitung dengan menggunakan rumus indeks dominansi Simpson (Odum, 1971) sebagai berikut:

Dimana:

$$
a=\sum\left(\frac{n i}{N}\right)^{2}
$$

$\mathrm{d} \quad=$ Indeks dominansi Simpson

$\mathrm{ni}=$ Jumlah individu dalam tiap spesies atau genera

$\mathrm{N}=$ jumlah total individu

\section{Analisis Statistika}

Analisis statistika yang digunakan dalam penelitian ini adalah analisis korelasi pearson yang digunakan untuk mengetahui hubungan logam berat kadmium dan timbal dengan kelimpahan total fitoplankton. Kedua, analisis statistika yang digunakan dalam penelitian ini adalah analisis Principle Component Analysis yang digunakan untuk mengetahui hubungan logam berat kadmium dan timbal dengan kelimpahan masing-masing genus fitoplankton.

\section{HASIL DAN PEMBAHASAN}

\section{HASIL}

Hasil Logam Berat Kadmium (Cd) dan Timbal (Pb)

Hasil pengukuran konsentrasi logam berat kadmium $(\mathrm{Cd})$ terlarut dari ketiga pengulangan sampling di setiap stasiun pengamatan dapat dilihat pada Tabel 1 sebagai berikut :

Tabel 1. Hasil Konsentrasi Logam Berat Kadmium Terlarut di Sungai Silandak

\begin{tabular}{cccccc}
\hline \multirow{2}{*}{$\begin{array}{c}\text { Logam } \\
\text { Berat }\end{array}$} & Ulangan & \multicolumn{3}{c}{ Konsentrasi Logam Kadmium } & Baku \\
& & $\mathbf{C}$ & $\mathbf{C}) \mathbf{~} \mathbf{\text { B }} \mathbf{l}$ & $\mathbf{C}$ & $\begin{array}{c}\text { Mutu* } \\
\mathbf{m g} / \mathbf{l}\end{array}$ \\
\cline { 3 - 5 } & 1 & 0.0010 & 0.0008 & 0.0008 & 0.001 \\
Kadmium & 2 & 0.0007 & 0.0009 & 0.0008 & 0.001 \\
$(\mathrm{Cd})$ & 3 & 0.0010 & 0.0009 & 0.0010 & 0.001 \\
\hline Rataan & $\mathrm{X}$ & 0.0009 & 0.0009 & 0.0009 & 0.001 \\
\hline SD & & 0.0001 & 0.0001 & 0.0001 & 0.001 \\
\hline
\end{tabular}

Sumber : Penelitian April 2016

*Baku Mutu Air Untuk Biota Keputusan Menteri Negara Lingkungan Hidup No. 51 Tahun 2004 
Berdasarkan data hasil pengukuran logam berat kadmium di stasiun A,B, dan C diperoleh angka logam kadmium $0.0008-0.0010 \mathrm{mg} / \mathrm{l}$ pada sampling pertama, dan $0.0007-0.0009 \mathrm{mg} / \mathrm{l}$ pada sampling kedua, serta sampling ketiga 0.0009-0.0010 mg/l. Rata-rata pada setiap stasiun sama angkanya yaitu 0.0009. Hasil pengukuran logam berat kadmium di Sungai Silandak termasuk kecil konsentrasinya dan tidak melebihi baku mutu $(0,001 \mathrm{mg} / \mathrm{l})$ yang telah ditetapkan oleh Keputusan Menteri Negara Lingkungan Hidup Nomor 51 Tahun 2004 tentang baku mutu air untuk biota air.

Hasil pengukuran logam berat Timbal $(\mathrm{Pb})$ terlarut dari ketiga pengulangan sampling di setiap stasiun pengamatan dapat dilihat pada Tabel 2 sebagai berikut:

Tabel 2. Konsentrasi Logam Berat Timbal $(\mathrm{Pb})$ Terlarut di Sungai Silandak

\begin{tabular}{|c|c|c|c|c|c|}
\hline \multirow{3}{*}{$\begin{array}{c}\text { Logam } \\
\text { Berat }\end{array}$} & \multirow{3}{*}{ Ulangan } & \multicolumn{3}{|c|}{ Konsentrasi Logam Timbal (Pb) } & \multirow{3}{*}{$\begin{array}{c}\text { Baku Mutu } \\
* \\
(\mathrm{mg} / \mathrm{l})\end{array}$} \\
\hline & & & $\mathrm{mg} / \mathrm{l}$ & & \\
\hline & & $\mathbf{A}$ & $\mathbf{B}$ & $\mathbf{C}$ & \\
\hline \multirow{3}{*}{ Timbal $(\mathrm{Pb})$} & 1 & 0.004 & 0.004 & 0.007 & 0.008 \\
\hline & 2 & 0.007 & 0.004 & 0.004 & 0.008 \\
\hline & 3 & 0.006 & 0.006 & 0.002 & 0.008 \\
\hline Rataan & $\bar{X}$ & 0.006 & 0.005 & 0.004 & 0.008 \\
\hline SD & & 0.002 & 0.001 & 0.003 & 0.008 \\
\hline
\end{tabular}

Sumber : Penelitian April 2016

*Baku Mutu Air Untuk Biota Keputusan Menteri Negara Lingkungan Hidup No. 51 Tahun 2004

Berdasarkan data hasil pengukuran logam berat timbal di stasiun A,B, dan $\mathrm{C}$ diperoleh angka 0.004 $0.007 \mathrm{mg} / \mathrm{l}$ pada sampling pertama, dan $0.004-0.007 \mathrm{mg} / \mathrm{l}$ pada sampling kedua, serta sampling ketiga 0.002 $0.006 \mathrm{mg} / \mathrm{l}$. Hasil tersebut tidak melebihi baku mutu $(0,008 \mathrm{mg} / \mathrm{l})$ yang telah ditetapkan Keputusan Menteri Negara Lingkungan Hidup No.51 Tahun 2004 tentang baku mutu air untuk biota air.

\section{Hasil Analisis Kelimpahan Fitoplankton}

Hasil analisis kelimpahan fitoplankton di Sungai Silandak.Nilai rata - rata pada setiap titik diambil untuk mengetahui kelimpahan fitoplankton pada setiap stasiun.Jenis fitoplankton yang ditemukan selama pengamatan di Laboratorium Pengelolaan Sumber Daya Ikan dan Lingkungan Kampus FPIK Undip terdiri dari 37 genera.Kelimpahan total fitoplankton yang tercacah dapat dilihat dalam gambar 3.sebagai berikut :

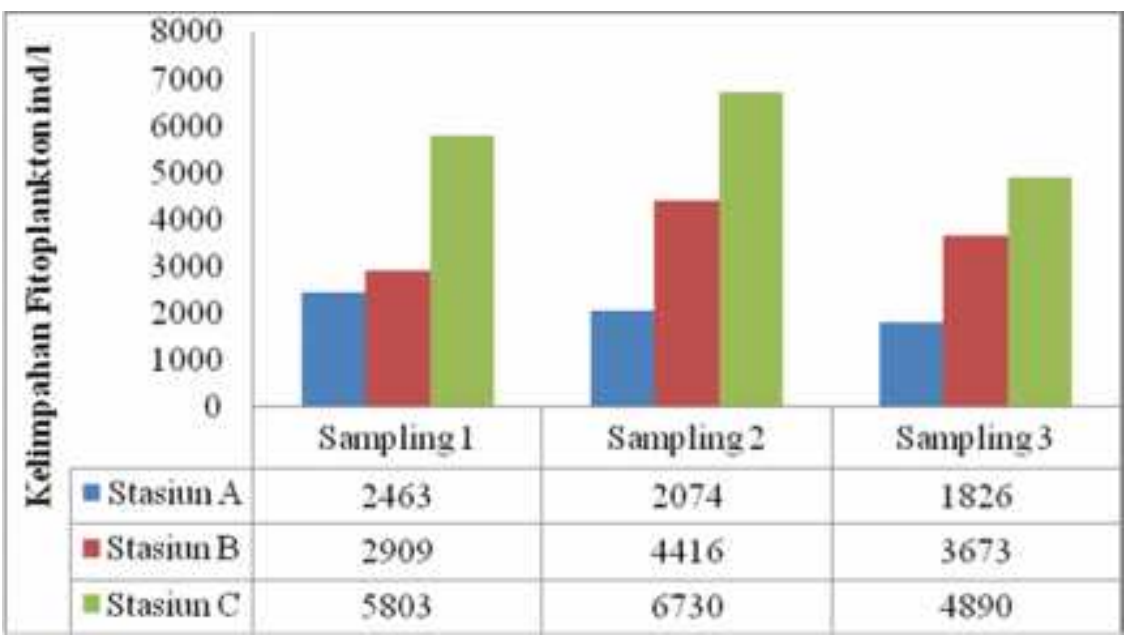

Gambar 3. Grafik Histogram Kelimpahan Fitoplankton

Berdasarkan hasil identifikasi dan analisis data kelimpahan fitoplankton diperoleh hasil kelimpahan pada sampling pertama di ketiga stasiun berkisar antara 2463 - 5803 ind/l. Kelimpahan fitoplankton pada sampling kedua di ketiga stasiun berkisar antara 2074 - 6730 ind/l, dan Kelimpahan fitoplankton pada sampling ketiga di setiap stasiun berkisar antara 1826 - 4890 ind/l.

\section{Hasil Analisis Struktur Komunitas Fitoplankton}

Hasil analisis struktur komunitas fitoplankton menggunakan nilai rata - rata individu pada setiap titik dari ketiga pengulangan sampling di setiap stasiun pengamatan diambil untuk mengetahui keanekaragaman $\left(\mathrm{H}^{\prime}\right)$, keseragaman (e), dan dominansi (d). Hasil analisis struktur komunitas fitoplankton dapat dilihat pada Tabel 3berikut :

\footnotetext{
두 Copyright by Management of Aquatic Resources (MAQUARES)
} 
Tabel 3. Analisis Struktur Komunitas Fitoplankton

\begin{tabular}{|c|c|c|c|c|c|}
\hline \multirow{2}{*}{ Pengulangan } & \multirow{2}{*}{ Stasiun } & \multirow{2}{*}{$\mathbf{S}$} & \multirow{2}{*}{$\begin{array}{c}\text { Keanekaragaman } \\
\text { H'}^{\prime}\end{array}$} & \multirow{2}{*}{$\begin{array}{c}\text { Dominasi } \\
\text { D }\end{array}$} & \multirow{2}{*}{$\begin{array}{c}\text { Keseragaman } \\
\mathbf{E} \\
\end{array}$} \\
\hline & & & & & \\
\hline \multirow{3}{*}{1} & A & 15 & 1.973 & 0.194 & 0.729 \\
\hline & B & 24 & 2.828 & 0.077 & 0.890 \\
\hline & $\mathrm{C}$ & 19 & 2.618 & 0.085 & 0.889 \\
\hline \multirow{3}{*}{2} & A & 15 & 1.747 & 0.284 & 0.645 \\
\hline & B & 26 & 2.689 & 0.099 & 0.825 \\
\hline & $\mathrm{C}$ & 21 & 2.661 & 0.086 & 0.874 \\
\hline \multirow{3}{*}{3} & A & 13 & 1.789 & 0.232 & 0.697 \\
\hline & B & 18 & 2.315 & 0.154 & 0.801 \\
\hline & $\mathrm{C}$ & 20 & 2.633 & 0.090 & 0.879 \\
\hline
\end{tabular}

Sumber : Penelitian April 2016

Berdasarkan hasil sampling pertama diperoleh indeks keanekaragaman (H') dengan angka 1.973 2.828.Indeks dominansi (d) 0.077-0.194 serta angka indeks keseragaman (e) 0.729 - 0.890.Sampling kedua diperoleh hasil indeks keanekaragaman $\left(\mathrm{H}^{\prime}\right)$ dengan angka diantara $1.747-2.689$, indeks dominansi (d) dengan angka $0.086-0.284$ dan hasil indeks keseragaman (e) dengan angka antara $0.645-0.874$.Sampling ketiga diperoleh hasil indeks keanekaragaman $\left(\mathrm{H}^{\prime}\right)$ dengan angka antara $1.789-2.633$, indeks dominansi (d) dengan angka $0.090-0.232$ dan nilai indeks keseragaman (e) dengan nilai $0.697-0.879$.

Hasil indeks keanekaragaman diperolehangka 1.747 - 2.828. Hal ini memiliki arti bahwa stabilitas komunitas biota sedang atau kualitas air tercemar sedang. Hasil indeks dominansi diperoleh hasil dengan angka 0.077 - 0.284.Hasil tersebut menggambarkan tidak terdapat genus yang mendominasi genus lainnya atau struktur komunitas dalam keadaan stabil.Hasil indeks keseragaman diperoleh hasil dengan angka $0.645-0.890$.Angka tersebut menggambarkan bahwa kemerataan antar genus relatif merata atau jumlah individu masing-masing genus relatif sama.

\section{Hubungan Kadmium dan Timbal dengan Kelimpahan Fitoplankton}

Analisiskorelasi digunakan untuk menganalisa hubungan antara konsentrasi kadmium dan timbal dengan kelimpahan fitoplankton. Hasil analisis korelasi yang digunakan dapat dilihat pada Tabel 4 sebagai berikut :

Tabel 4. Analisis Uji Korelasi Pearson Konsentrasi Cd dan $\mathrm{Pb}$ dengan Kelimpahan Fitoplankton

\begin{tabular}{lccc}
\hline \multirow{2}{*}{\multicolumn{1}{c}{ Analisa Uji }} & Korelasi & Determinasi & Signifikan $\boldsymbol{\alpha}$ \\
\cline { 2 - 4 } & $\mathbf{R}$ & $\mathbf{R}^{\mathbf{2}}$ & $\mathbf{0 . 0 5}(\mathbf{9 5 \% )}$ \\
\hline Kadmium $(\mathrm{Cd})$ dengan Kelimpahan & -0.179 & 0.032 & 0.646 \\
Timbal $(\mathrm{Pb})$ dengan Kelimpahan & -0.261 & 0.068 & 0.497 \\
\hline
\end{tabular}

Sumber : Uji Korelasi Pearson SPSS 23 Statistik

Berdasarkan hasil analisis korelasi pearson dengan menggunakan taraf kepercayaan $95 \%(\alpha=0,05)$ yang dilihat dengan angka signifikansi (Sig.). Angka koefisien korelasi (r) sebesar -0.179 menunjukkan korelasi kadmium terhadap kelimpahan fitoplankton memiliki korelasi sangat lemah.Angka koefisien determinasi $\left(\mathrm{R}^{2}\right)$ sebesar 0.0319 menunjukkan sebesar 3\% kelimpahan fitoplankton dipengaruhi oleh kadmium. Signifikasi sebesar 0.646 lebih besar dari $\alpha=0.05$ dapat disimpulkan bahwa konsentrasi logam kadmium tidak memiliki hubungan dengan kelimpahan fitoplankton.

Berdasarkan hasil analisis korelasi pearson dengan menggunakan taraf kepercayaan $95 \%(\alpha=0,05)$ yang dilihat dengan angka signifikansi (Sig.). Angka koefisien korelasi (r) sebesar -0.261 menunjukkan korelasi antara timbal dengan kelimpahan fitoplankton lemah.Angka koefisien determinasi $\left(\mathrm{R}^{2}\right)$ sebesar 0.068 menunjukkan sebesar $6 \%$ kelimpahan fitoplankton dipengaruhi oleh timbal $(\mathrm{Pb})$. Signifikasi sebesar 0.497 lebih besar dari $\alpha=$ 0.05 dapat disimpulkan bahwa konsentrasi logam timbal setiap stasiun tidak memiliki hubungan dengan kelimpahan fitoplankton. 


\section{Principle Component Analysis (PCA)}

Principle Component Analysis digunakan untuk mengetahui hubungan antara logam berat kadmium dan timbal dengan kelimpahan genus fitoplankton. Hasil analisis Principle Component Analysis dapat dilihat pada Gambar 4 berikut ini :

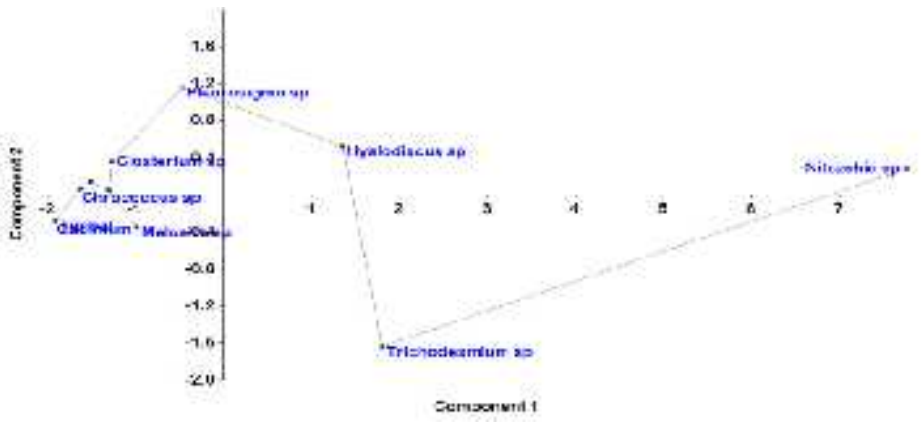

Gambar 4. Uji PCA Logam Berat dengan Genus Fitoplankton

Berdasarkan gambar Uji Principle Component Analysis dapat dilihat bahwa logam berat kadmium memiliki korelasi lemah dengan kelimpahan Coelastrum sp, Melosira sp, dan Chrococcus sp dengan angka koefisien korelasi (r) sebesar 0.30, -0.33, dan -0.32 dan hubungan kadmium dengan kelimpahan genus lainnya memiliki korelasi sangat lemah. Logam berat timbal memiliki korelasi cukup erat dengan kelimpahan genus Nitszchia sp dengan angka koefisien korelasi (r) sebesar 0.47 .

Hasil analisis Principle Component Analysis(PCA) dapat dilihat pada Gambar 5.berikut ini :

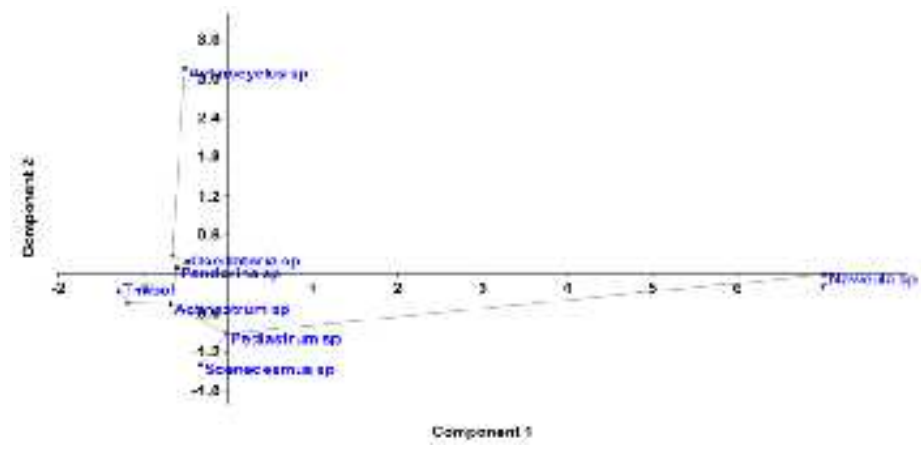

Gambar 5. Uji PCA Logam Berat dengan Genus Fitoplankton

Berdasarkan gambar Uji Principle Component Analysis dapat dilihat bahwa konsentrasi logam berat kadmium dengan kelimpahan genus Scenedesmus sp dan Stigeoclonium sp memiliki korelasi cukup erat dengan angka koefisien korelasi (r) sebesar 0.55 dan 0.41 dan memiliki korelasi lemah dengan genus lainnya. Logam berat timbal dengan kelimpahan genus Scenedesmus sp memiliki korelasi cukup erat sebesar - 0.44 dan memiliki korelasi lemah dengan genus lainnya.Tidak adanya hubungan yang signifikan antara logam berat kadmium dan timbal dengan kelimpahan genus tersebut.

Hasil analisis Principle Component Analysis dapat dilihat pada Gambar 6 berikut ini :

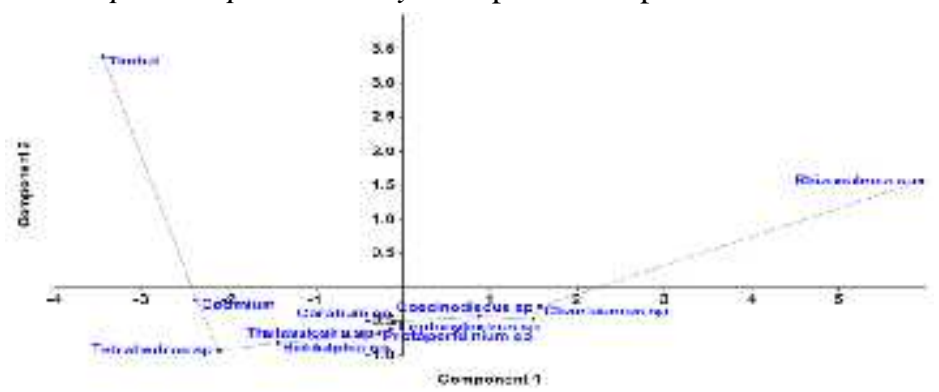

Gambar 6. Uji PCA Logam Berat dengan Genus Fitoplankton

Berdasarkan gambar Uji Principle Component Analysis dapat dilihat bahwa konsentrasi logam berat kadmium dengan kelimpahan genus Coscinodiscus sp, Tetrahedron sp dan Biddulphia sp memiliki korelasi lemah dengan angka koefisien korelasi (r) sebesar -026, -0.26 dan -0.34 dan memiliki korelasi sangat lemah dengan genus lainnya. Logam berat timbal dengan kelimpahan genus Rhizosolenia sp memiliki korelasi cukup erat dengan koefisien korelasi (r) sebesar - 0.43 dan memiliki korelasi lemah dengan kelimpahan genus

${ }^{\circ}$ Copyright by Management of Aquatic Resources (MAQUARES) 
lainnya.Tidak adanya hubungan yang signifikan antara logam berat kadmium dan timbal dengan kelimpahan genus tersebut.

Hasil analisis Principle Component Analysis dapat dilihat pada Gambar 7 berikut ini :

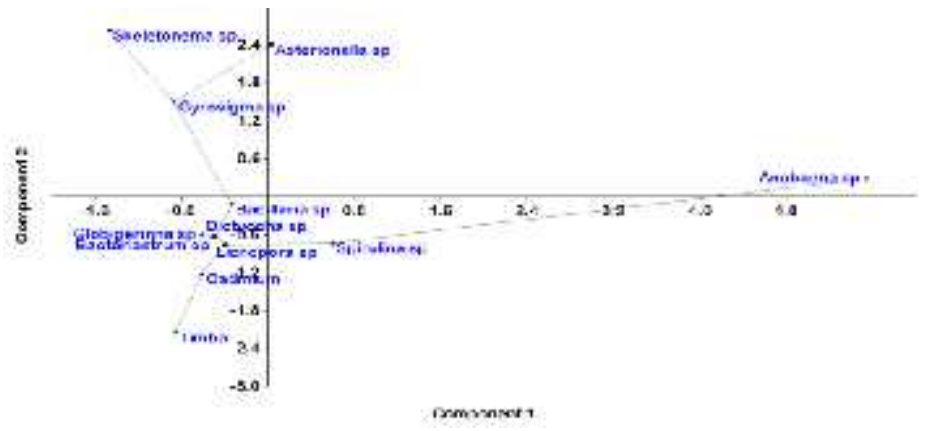

Gambar 7. Uji PCA Logam Berat dengan Genus Fitoplankton

Berdasarkan gambar Uji Principle Component Analysis dapat dilihat bahwa konsentrasi logam berat kadmium dengan kelimpahan genus Anabaena sp, Spirulina sp dan Bacillaria sp memiliki korelasi cukup erat dengan angka koefisien korelasi (r) sebesar 0.50, 0.43, 0.41 dan memiliki korelasi lemah dengan genus lainnya. Logam timbal dengan kelimpahan genus Dictyocha sp dan Bacteriastrum sp memiliki korelasi kuat dengan koefisien korelasi (r) sebesar -0.68 dan -0.68, logam timbal dengan kelimpahan genus Gyrosigma sp, Globigerinna sp, dan Bacillaria sp memiliki korelasi cukup erat dengan koefisien korelasi (r) sebesar -0.61, 0.46, -064 dan memiliki korelasi lemah dengan genus lainnya. Terdapat hubungan signifikan logam berat timbal dengan kelimpahan genus Dyctyocha sp dan Bacteriastrum sp dilevel 0.05 dari rentang kepercayaan $95 \%$ (0.05).

\section{PEMBAHASAN}

\section{Konsentrasi Logam Berat Kadmium dan Timbal}

Berdasarkan hasil penelitian logam berat kadmium dan timbal di Sungai Silandak diperoleh hasil $0.0007-0.0010 \mathrm{mg} / \mathrm{l}$ untuk angka kadmium pada ketiga pengulangan sampling di setiap stasiun, dan timbal diperoleh hasil $0.002-0.007 \mathrm{mg} / 1$.Konsentrasi logam berat kadmium dan timbal yang rendah disebabkan oleh rendahnya sumber pencemar yang masuk ke dalam badan perairan. Menurut Widowati et al. (2008) bahwa berdasarkan hasil pencemaran rata-rata konsentrasi kadmium disekitar industri electroplating adalah sebesar $0.0830 \mathrm{mg} / \mathrm{l}$, industri percetakan sebesar $0.0731 \mathrm{mg} / \mathrm{l}$, industri plastik sebesar $0.0060 \mathrm{mg} / \mathrm{l}$ dan industri makanan sebesar $0.0066 \mathrm{mg} / \mathrm{l}$. Menurut Effendi (2003), untuk melindungi kehidupan ekosistem akuatik, perairan sebaiknya memiliki konsentrasi kadmium 0,0002 mg/liter.

Konsentrasi timbal yang rendah disebabkan karena lokasi Sungai Silandak sedikit dilalui oleh transportasi air yang menjadi sumber pencemar utama pencemaran timbal, serta kemungkinan industri disekitar aliran Sungai Silandak memiliki sistem pengolahan air limbah yang baik sebelum dialirkan kedalam badan perairan. Hasil timbal diperoleh antara $0.002-0.007 \mathrm{mg} / \mathrm{l}$. Menurut Effendi (2003), bahwa timbal tidak termasuk unsur yang esensial bagi makhluk hidup, bahkan unsur ini bersifat toksik bagi hewan dan manusia. Konsentrasi timbal diperairan alami $0.0003 \mathrm{mg} / \mathrm{l}$.

Perindustrian di era modern seperti ini telah memiliki bentuk pengolahan air limbah yang baik.Konsentrasi logam berat yang digunakan sebagai bahan produksi telah diolah sedemikian rupa sebelum dialirkan kedalam badan perairan agar tidak menimbulkan pencemaran air dan lingkungan. Air limbah yang dialirkan ke badan perairan telah melalui proses pengurangan konsentrasi logam berat terlarut.

Hal ini diperkuat oleh Gintings (1992), proses adsorpsi tersebut terjadi melalui media filtrasi. Proses penyaringan ini zat padat tersuspensi dihilangkan pada waktu air melalui lapisan materi berbentuk butiran yang disebut media filter. Media filter terdiri atas berbagai jenis diantarnya pasir, karbon aktif, dan zeolit. Pada pengolahan penjernihan air yang digunakan untuk mengurangi pengotoran bahan organik, mengurangi konsentrasi bahan-bahan logam terlarut.Pasir kuarsa juga dapat bereaksi dengan logam berat dengan mengubah ion logam fluida menjadi padatan atau presiparat.Zeolit digunakan untuk mengurangi konsentrasi bahan-bahan logam terlarut seperti $\mathrm{Na}, \mathrm{Mg}, \mathrm{Ca}, \mathrm{Cd}, \mathrm{Pb}$ dan $\mathrm{Fe}$. Zeolit biasanya ditulis dengan reaksi kimia oksida atau berdasarkan sel kristal.

\section{Kelimpahan dan Struktur Komunitas Fitoplankton}

Berdasarkan hasil identifikasi dan analisis data kelimpahan fitoplankton diperoleh hasil kelimpahan dari seluruh pengulangan sampling disetiap stasiun pengamatan nilai kelimpahan berkisar antara 1826 - 6730 ind/l. Dapat disimpulkan bahwa kelimpahan fitoplankton di Sungai Silandak cukup baik. Hal ini sesuai dengan pernyataan Soegianto (1994) dalam Madinawati (2010), bahwa kelimpahan dengan nilai < 1.000 ind/l termasuk

\footnotetext{
(C) Copyright by Management of Aquatic Resources (MAQUARES)
} 
rendah, kelimpahan antara $1.000-40.000$ ind/l tergolong sedang, dan kelimpahan > 40.000 ind/l tergolong tinggi.

Kelimpahan yang cukup baik di Sungai Silandak disebabkan karena rendahnya konsentrasi logam berat kadmium dan timbal terlarut.Konsentrasi logam berat kadmium dan timbal di wilayah pengamatan masih dapat ditoleransi oleh fitoplankton. Hal ini diperkuat oleh Lestari (2004), logam berat bersifat akumulatif, sifat racunnya baru muncul bila logam berat tersebut terakumulasi dalam konsentrasi yang relatif tinggi dalam tubuh biota, keadaan ini tercapai dalam waktu yang cukup lama, sehingga tidak dapat menimbulkan kematian secara mendadak.

Indeks keanekaragaman yang cukup baik di Sungai Silandak didukung dengan diidentifikasinya total 37 genera fitopankton. Indeks keanekaragaman fitoplankton di Sungai Silandak dari total stasiun pengamatan berkisar antara 1.747 - 2.828. Hasil analisis keanekaragaman $\left(\mathrm{H}^{\prime}\right)$ fitoplankton memperlihatkan bahwa seluruh stasiun termasuk stabil moderat.Menurut Stirn (1981) dalam Pirzan, et al. (2008), bahwa apabila H' < 1, maka komunitas biota dinyatakan tidak stabil, apabila H' berkisar 1-3 maka stabilitas komunitas biota tersebut adalah moderat (sedang) dan apabila $H^{\prime}>3$ berarti stabilitas komunitas biota berada dalam kondsi prima (stabil).Semakin besar nilai H' menunjukkan semakin beragamnya kehidupan di perairan tersebut, kondisi ini merupakan tempat hidup yang lebih baik.

\section{Hubungan Logam Berat Kadmium dan Timbal dengan Kelimpahan Fitoplankton}

Hasil analisis korelasi logam berat kadmium dengan kelimpahan fitoplankton diperoleh angka koefisien korelasi (r) sebesar -0.179, menunjukkan korelasi kadmium terhadap kelimpahan fitoplankton memiliki korelasi sangat lemah.Angka koefisien determinasi $\left(\mathrm{R}^{2}\right)$ sebesar 0.0319 menunjukkan sebesar 3\% kelimpahan fitoplankton dipengaruhi oleh kadmium.Hasil analisis korelasi logam berat timbal dengan kelimpahan fitoplankton diperoleh angka koefisien korelasi (r) sebesar -0.261, menunjukkan korelasi antara timbal dengan kelimpahan fitoplankton lemah.Angka koefisien determinasi $\left(\mathrm{R}^{2}\right)$ sebesar 0.068 menunjukkan sebesar $6 \%$ kelimpahan fitoplankton dipengaruhi oleh timbal.Tidak ada hubungan yang signifikan dari taraf kepercayaan 95\% antara logam berat kadmium dan timbal dengan kelimpahan fitoplankton.

Hasil Uji Principle Component Analysis dapat dilihat bahwa logam berat kadmium memiliki korelasi lemah dengan kelimpahan Coelastrum sp, Melosira sp, Chrococcus sp, Coscinodiscus sp, Tetrahedron sp dan Biddulphia sp dengan angka koefisien korelasi (r) dengan angka 0.30, -0.33, -0.32, 026, -0.26, dan -0.34. Logam berat kadmium dengan kelimpahan genus Scenedesmus sp, Stigeoclonium sp, Anabaena sp, Spirulina sp dan Bacillaria sp memiliki korelasi cukup dengan angka koefisien korelasi (r) 0.55, 0.41, 0.50, 0.43, dan 0.41.Tidak ada hubungan yang signifikan antara kadmium dengan kelimpahan genus fitoplankton tersebut. Menurut Sulardiono, et al. (2015), spesies algae yang berpotensi teradsorbsi logam berat antara lain Scenedesmus acutus, Chaetoceros sp, Anabaena, Phormidium sp, Cladophora glomerata, Galaxaura rugosa, Euchema isiforme,Corallina sp, Fucus vesiculosus, Bacillaria sp, Padina boergesenii, Nostoc sp dan Sargassum sp.

Korelasi lemah antara timbal dengan kelimpahan genus Pellaghotrix sp dan Closterium sp dengan angka koefisien korelasi (r)0.27 dan -0.24. Logam berat timbal memiliki korelasi cukup dengan kelimpahan genus Nitszchia sp, Scenedesmus sp, Gyrosigma sp, Globigerinna sp, dan Bacillaria sp memiliki korelasi cukup dengan angka koefisien korelasi (r) 0.47, -0.44, -0.61, 0.46, dan -064. Logam timbal dengan kelimpahan genus Dictyocha sp dan Bacteriastrum sp memiliki korelasi kuat dengan koefisien korelasi (r) -0.68 dan -0.68. Terdapat hubungan signifikan logam berat timbal dengan kelimpahan genus Dyctyocha sp dan Bacteriastrum $\mathrm{sp}$ dilevel 0.05 dari rentan kepercayaan ( $\alpha$-sig) $95 \%$. Menurut Sulardiono, et al. (2015) suatu lingkungan yang memiliki tingkat kandungan logam berat yang melebihi jumlah yang diperlukan dapat mengakibatkan kelimpahan dan pertumbuhan terhambat. Sehingga dalam keadaan ini eksistensi logam dalam lingkungan adalah pencemar.

\section{KESIMPULAN}

Berdasarkan hasil penelitian yang telah dilakukan, dapat disimpulkan sebagai berikut :

1. Angka konsentrasi kadmium pada keseluruhan sampling berkisar antara 0.0007-0.0010 mg/l, sedangkan angka konsentrasi timbal pada keseluruhan sampling berkisar antara $0.002-0.007 \mathrm{mg} / \mathrm{l}$.

2. Kelimpahan fitoplankton di Sungai Silandak pada keseluruhan sampling berkisar antara $1826-6730$ ind/l. Indeks keanekaragaman (H') fitoplankton pada keseluruhan sampling diperoleh angka 1.747 - 2.828. Hal ini memiliki arti bahwa kualitas air tercemar sedang dan stabilitas biota sedang. Indeks dominasi (d) diperoleh hasil dengan angka 0.077 - 0.284 menggambarkan bahwa tidak terdapat genus yang mendominasi dan indeks keseragaman (e) dengan angka 0.645 - 0.890 hal ini menggambarkan kemerataan masing-masing genus relatif sama.

3. Tidak ada hubungan yang signifikan antara kadmium dan timbal dengan kelimpahan fitoplankton. Angka koefisien korelasi (r) sebesar 0.179 menunjukkan korelasi lemah antara kadmium dengan kelimpahan fitoplankton.Angka koefisien korelasi (r) sebesar 0.261, menunjukkan korelasi lemah antara timbal dengan kelimpahan fitoplankton. Namun, terdapat hubungan signifikan logam berat timbal dengan kelimpahan genus

\footnotetext{
() Copyright by Management of Aquatic Resources (MAQUARES)
} 
Dyctyocha sp dan Bacteriastrum sp di level 0.05 dari rentang kepercayaan $95 \%$, Korelasi kuat dengan koefisien korelasi (r) sebesar -0.68 .

\section{UCAPAN TERIMAKASIH}

Penulis mengucapkan terimakasih kepada Prof. Norma Afiati, M.Sc., Ph.D, Dra. Niniek Widyorini, M.S, Dr. Ir. Max Rudolf Muskananfola, M.Sc, dan Dr. Ir. Pudjiono Wahyu Purnomo, M.S atas segala kritik dan saran yang diberikan dalam hasil penelitian ini serta semua pihak yang telah membantu dalam penyusunan skripsi ini.

\section{DAFTAR PUSTAKA}

APHA American Public Health Association, American Water Works Association dan Water Pollution Control Federation. 2012. Standart Methods for The Examination of Water and Wastewater 25th Edition. American Public Health Assoiation. Washington D.C., 1193 p.

Edward, G.B. dan C.S. David. 2010. Freshwater Algae Identification and Use as Bioindicators. John Wiley and Sons, Ltd. London, 254 p.

Effendi, H. 2003.Telaah Kualitas Air bagi Pengelolaan Sumber Daya dan Lingkungan Perairan.Kanisius. Yogyakarta, $258 \mathrm{hlm}$.

Lestari.dan Edward. 2004. Dampak Pencemaran Logam Berat Terhadap Kualitas Air Laut dan Sumberdaya Perikanan (Studi Kasus Kematian Massal Ikan-Ikan di Teluk Jakarta). Pusat Penelitian Oseanografi, Lembaga Ilmu Pengetahuan Indonesia. Jakarta. Jurnal Makara Sains. Vol. 8 (2) 52-58.

Madinawati. 2010. Kelimpahan dan Keanekaragaman Plankton Di Perairan Laguna Desa Tolongano Kecamatan Banawa Selatan. Jurnal Media Litbang Sulteng. Universitas Tadulako Vol 3 (2) hal 119-123

Odum, E.P. 1993. Fundamentals of Ecology.W.B Saunders co. Philadelpia, 696 p.

Palar, H. 2008.Pencemaran dan Toksikologi Logam Berat. Rineka Cipta. Jakarta, 151 hlm.

Perdana, G. 1992. Mencegah dan Mengendalikan Pencemaran Industri. Pustaka Sinar Harapan. Jakarta, 232 hlm.

Pirzan, A.M. dan P.R. Pong-masak.2008. Hubungan Keragaman Fitoplankton dengan Kualitas Air di Pulau Bauluang, Kabupaten Takalar, Sulawesi Selatan.Jurusan Biologi FMIPA UNS. Surakarta.Jurnal Biodiversitas Vol 9 (3) hal 217-221.

Sulardiono, B. S. Hutabarat dan A. Djunaedi. 2015. Buku Ajar Planktonologi. Badan Penerbit Universitas Diponegoro. ISBN.Semarang, $118 \mathrm{hlm}$.

Widowati, W., A. Sastiono dan J.R. Raymond. 2008. Efek Toksik Logam. Andi.Yogyakarta.410 hlm.

Yamaji, I. 1996. Illustration of the Marine Plankton of Japan. Hoikusho, Japan. 437 hlm 